\title{
Oral Processing, Satiation and Obesity: Overview and Hypotheses: A Short Comment [Letter]
}

\author{
Reza Rastmanesh (iD) ${ }^{1,2}$ \\ 'The Nutrition Society, London, UK; \\ ${ }^{2}$ The American Physical Society, Maryland \\ State, MD, USA
}

\section{Dear editor}

I read with interest the article by Dr. Arnold Slyper. ${ }^{1}$ I would like to suggest adding some brief and useful points to his core conclusion to provide a consolidated overview.

Dr. Arnold Slyper has done a brilliant attempt to overview the obesity form the perspective of current hypotheses on oral processing and satiation. As the author stated, he has focused to present an overview pertaining specifically to the hypotheses pertaining to six areas related to aspects of oral processing.

As the author has pointed out, salivation and lubrication of the food bolus to make it suitable for swallowing, enzymatic activity on the food ingested, sensations within the mouth arising from the food, and finally swallowing of the bolus are amongst the many physiological processes within the mouth which are involved in dealing with food. However, less attention has been paid to the role of salivation in oral processing in that paper.

It is very important to notice that there are also significant inter-individual differences on salivary flow rates (for instance, in patients with diabetic people, ${ }^{2}$ schoolchildren, ${ }^{3}$ otherwise healthy individuals ${ }^{4}$ ), as well as age- and sex-related differences in masseter size and its role in oral functions ${ }^{5}$ and consequently oral processing of foods.

Salivary response has long been known to mediate olfactory food stimuli as a function of dietary restraint and body weight. ${ }^{6}$ Indeed, there is a tight correlation between salivary flow rates and total food/nutrient intake and food preference. ${ }^{7-9}$ All these information are important, since both hypo and hypersecretion of saliva is implicated in obesity. These evidences are relevant since salivary flow rates are associated with obesity, ${ }^{10}$ metabolic syndrome, ${ }^{11}$ noninsulin-dependent diabetes mellitus and obesity-insulin resistance. ${ }^{12}$

Taking into account these neglected associations and differences would undoubtedly help in targeting the best strategy to treat/prevent obesity and/or related disorders in different pathologic conditions (such as Sjogren syndrome, xerostomia, etc.), treatments (xerogenic/xerostomic medicaments, etc.) and settings (long-term radiation/chemotherapy, etc.).

\section{Disclosure}

The author reports no conflicts of interest in this communication. 


\section{References}

1. Slyper A. Oral processing, satiation and obesity: overview and hypotheses. Diabetes Metab Syndr Obes. 2021;14:3399-3415. doi:10.2147/DMSO.S314379

2. Reuterving CO, Reuterving G, Hagg E, et al. Salivary flow rate and salivary glucose concentration in patients with diabetes mellitus influence of severity of diabetes. Diabete Metab. 1987;13(4): $457-462$.

3. Tukia-Kulmala $\mathrm{H}$, Tenovuo J. Intra- and inter-individual variation in salivary flow rate, buffer effect, lactobacilli, and mutans streptococci among 11- to 12-year-old schoolchildren. Acta Odontol Scand. 1993;51(1):31-37. doi:10.3109/00016359309041145

4. Won S, Kho H, Kim Y, et al. Analysis of residual saliva and minor salivary gland secretions. Arch Oral Biol. 2001;46(7):619-624. doi:10.1016/S0003-9969(01)00018-8

5. Lin CS, Wu CY, Wu SY, et al. Age- and sex-related differences in masseter size and its role in oral functions. $J$ Am Dent Assoc. 2017;148 (9):644-653. doi:10.1016/j.adaj.2017.03.001

6. Legoff DB, Spigelman MN. Salivary response to olfactory food stimuli as a function of dietary restraint and body weight. Appetite. 1987;8(1):29-35. doi:10.1016/S0195-6663(87)80024-7
7. Bergdahl M, Bergdahl J. Perceived taste disturbance in adults: prevalence and association with oral and psychological factors and medication. Clin Oral Investig. 2002;6(3):145-149. doi:10.1007/ s00784-002-0169-0

8. Ernest SL. Dietary intake, food preferences, stimulated salivary flow rate, and masticatory ability in older adults with complete dentitions. Spec Care Dentist. 1993;13(3):102-106. doi:10.1111/j.1754-4505.1993.tb01628.x

9. Kedjarune U, Migasena P, Changbumrung S, et al. Flow rate and composition of whole saliva in children from rural and urban Thailand with different caries prevalence and dietary intake. Caries Res. 1997;31(2):148-154. doi:10.1159/000262390

10. Maruyama K, Nishioka S, Miyoshi N, et al. The impact of masticatory ability as evaluated by salivary flow rates on obesity in Japanese: the Toon health study. Obesity (Silver Spring). 2015;23(6): 1296-1302. doi:10.1002/oby.21071

11. Tremblay M, Brisson D, Gaudet D. Association between salivary $\mathrm{pH}$ and metabolic syndrome in women: a cross-sectional study. $B M C$ Oral Health. 2012;12(1):40. doi:10.1186/1472-6831-12-40

12. Ittichaicharoen J, Chattipakorn N, Chattipakorn SC. Is salivary gland function altered in noninsulin-dependent diabetes mellitus and obesity-insulin resistance? Arch Oral Biol. 2016;64:61-71. doi:10.1016/j.archoralbio.2016.01.002

Dove Medical Press encourages responsible, free and frank academic debate. The content of the Diabetes, Metabolic Syndrome and Obesity: Targets and Therapy 'letters to the editor' section does not necessarily represent the views of Dove Medical Press, its officers, agents, employees, related entities or the Diabetes, Metabolic Syndrome and Obesity: Targets and Therapy editors. While all reasonable steps have been taken to confirm the content of each letter, Dove Medical Press accepts no liability in respect of the content of any letter, nor is it responsible for the content and accuracy of any letter to the editor.

Diabetes, Metabolic Syndrome and Obesity: Targets and Therapy

\section{Dovepress}

\section{Publish your work in this journal}

Diabetes, Metabolic Syndrome and Obesity: Targets and Therapy is an international, peer-reviewed open-access journal committed to the rapid publication of the latest laboratory and clinical findings in the fields of diabetes, metabolic syndrome and obesity research. Original research, review, case reports, hypothesis formation, expert opinion and commentaries are all considered for publication. The manuscript management system is completely online and includes a very quick and fair peer-review system, which is all easy to use. Visit http://www.dovepress.com/testimonials.php to read real quotes from published authors. 